\title{
Analysis of sports science perceptions and research needs among South African coaches
}

\author{
A Kubayi, ${ }^{1,2}$ DPhil; Y Coopoo, ${ }^{2}$ DPhil, FACSM; A Toriola, ${ }^{1} \mathrm{PhD}$ \\ ${ }^{1}$ Department of Sport, Rehabilitation and Dental Sciences, Faculty of \\ Science, Tshwane University of Technology, Pretoria, South Africa \\ 2 Department of Sport and Movement Studies, Faculty of Health Sciences, \\ University of Johannesburg, South Africa
}

\section{Corresponding author: A Kubayi (kubayina@tut.ac.za)}

Background: There appears to be a gap between coaches' expectations concerning their needs and the focus of research findings published by sports scientists. Given the important role of sports science in enhancing athletic performance, closing the gap between sports scientists and coaches is expedient.

Objectives: To investigate sports science perceptions and research needs among South African coaches.

Methods: Using a cross-sectional survey design, a total of 202 (28 females and 174 males) purposively recruited South African coaches completed a validated questionnaire.

Results: Findings indicated that improving the technique/efficiency of athletes $(4.3 \pm 0.8)$, reducing the incidence of injury/illness in athletes $(4.3 \pm 0.8)$, helping athletes peak for competition $(4.3 \pm 0.9)$, and the mental preparation of athletes $(4.3 \pm 1.0)$ were reported as the most preferred areas of research by coaches. The coaches also reported that there is a need/role for sports science researchers to translate scientific literature into easily understandable language $(3.9 \pm 1.0)$. The coaches also indicated that the knowledge of sports science was important for them in performing their roles as coaches $(3.9 \pm 1.0)$

Conclusion: These findings have practical implications for sports federations to revise their coach education programmes to include sports science concepts which can be applied by coaches to improve the sports performance of individual athletes and teams.

Keywords: coaching, performance, knowledge

S Afr J Sports Med 2018;30:1-4. DOI: 10.17159/2078-516X/2018/v30i1a4240

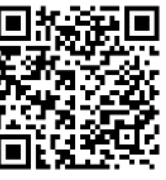

Sports science is a discipline that studies the processes used to guide the practice of sport with the primary goal of enhancing performance ${ }^{[1]}$ and reducing the risk of injury. [2] Sports science research benefits from two worlds of science, namely, pure and applied. The former serves to expand and explore the nature of things and forms the basic framework upon which all practical knowledge develops; the latter deals with the integration and application of science to the phenomenon of sport (e.g. sports biomechanics, exercise physiology, sports nutrition, and exercise/sports psychology). ${ }^{[3]}$ It is in the applied form that sports scientists provide answers to the questions that are often asked by coaches and technical personnel in the important areas of talent identification, physical fitness, monitoring, team selection, and training methods.

The applied sciences are beneficial for the large number of sports scientists who provide vital support to the athlete. Whilst basic research in sports science is predominantly performed by academics and usually published, applied research may result in a publication, but the real-world outcome it produces is one that is relevant to sports or can be applied in the sporting environment in order to improve an athlete's performance or reduce the incidence of injury. ${ }^{[2]}$ Haff [4] describes sports science as an applied rather than a basic science as it is a combination of development, research, innovation, and application. Bishop et al. ${ }^{[2]}$ reported that the application of sports science occurs if the coach and/or scientist uses the information obtained from such research to intervene realistically in the training and/or performance of an athlete. Sports science research, therefore, should address questions that have the potential to improve performance. [2]

Sports coaches need to have a foundation of sports science knowledge in order to enhance athletes' performance. Therefore, coaches should steep themselves in the scientific and technological aspects of sports so that they can help the athletes to improve their skills. As Haff ${ }^{[4]}$ purported, coaches need to have a basic understanding of nutrition, biomechanics, physiological adaptations of training, and scientific principles that form a foundation of training, but they also need to understand the research process. Haff ${ }^{[4]}$ further contended that coaches also need to have some basic sports science training because they are the end users of the sports science information, and with basic knowledge in that area they can make objective judgments in their coaching process rather than solely relying on their personal experiences as coaches and/or former athletes.

Several studies have been conducted on the perceived sports science needs among coaches in other countries. Examples of such studies are those conducted in Australia, ${ }^{\left[{ }^{5]}\right.}$ Canada, ${ }^{[6]}$ and and Turkey ${ }^{[7]}$. Kilic and Ince ${ }^{[7]}$ observed that these studies have made significant positive impacts in transmitting relevant scientific knowledge to the coaches and the athletes. However, from a South African standpoint, there appears to be a discrepancy between coaches' expectations concerning their needs and the focus of the findings published by sports scientists. It is, therefore, important to know how sports science research could better meet the actual needs of coaches and better fit into their coaching practice.

\section{Methods}

\section{Experimental design}

This study adopted a cross-sectional survey design.

\section{Participants}

A total of 202 (28 females and 174 males) sports coaches, aged 18 to 60 years (mean age: 32 years), were purposively recruited to participate in this study. The participants were selected on the basis that they were coaching priority sports as categorised by the Department of Sport and Recreation. 
Table 1. Preference for research areas

\begin{tabular}{|c|c|c|c|c|c|}
\hline & All & IEC & EC & & \\
\hline Variable & $\begin{array}{l}\text { Mean } \\
\pm \text { SD }\end{array}$ & $\begin{array}{l}\text { Mean } \\
\pm \text { SD }\end{array}$ & $\begin{array}{l}\text { Mean } \\
\pm \text { SD }\end{array}$ & $\begin{array}{l}\text { Effect } \\
\text { Size }\end{array}$ & $\begin{array}{c}\text { p- } \\
\text { value }\end{array}$ \\
\hline $\begin{array}{l}\text { Improving the technique/ } \\
\text { efficiency of athletes }\end{array}$ & $4.3 \pm 0.8$ & $4.3 \pm 0.8$ & $4.4 \pm 0.8$ & 0.1 & 0.2 \\
\hline $\begin{array}{l}\text { Reducing the incidence of } \\
\text { injury/illness in athletes }\end{array}$ & $4.3 \pm 0.8$ & $4.2 \pm 0.8$ & $4.4 \pm 0.7$ & 0.3 & $0.0^{*}$ \\
\hline $\begin{array}{l}\text { Helping athletes peak for } \\
\text { competition }\end{array}$ & $4.3 \pm 0.9$ & $4.2 \pm 0.9$ & $4.4 \pm 0.8$ & 0.2 & 0.0 \\
\hline Mental preparation of athletes & $4.3 \pm 1.0$ & $4.1 \pm 1.0$ & $4.4 \pm 0.9$ & 0.3 & $0.0^{*}$ \\
\hline $\begin{array}{l}\text { Development of recovery } \\
\text { techniques for athletes }\end{array}$ & $4.3 \pm 0.9$ & $4.2 \pm 0.9$ & $4.3 \pm 0.9$ & 0.1 & 0.2 \\
\hline $\begin{array}{l}\text { The development of strength/ } \\
\text { power in athletes }\end{array}$ & $4.2 \pm 0.9$ & $4.2 \pm 1.0$ & $4.3 \pm 0.8$ & 0.1 & 0.3 \\
\hline $\begin{array}{l}\text { Enhanced aerobic stamina of } \\
\text { athletes }\end{array}$ & $4.1 \pm 1.0$ & $4.0 \pm 1.0$ & $4.2 \pm 1.0$ & 0.2 & 0.2 \\
\hline Speed recovery from injury & $4.0 \pm 1.0$ & $3.9 \pm 1.1$ & $4.1 \pm 1.0$ & 0.2 & 0.2 \\
\hline $\begin{array}{l}\text { Nutrition supplementation for } \\
\text { athletes }\end{array}$ & $3.9 \pm 1.1$ & $3.8 \pm 1.2$ & $4.1 \pm 1.0$ & 0.3 & 0.1 \\
\hline Weight control for athletes & $3.9 \pm 1.0$ & $3.8 \pm 1.0$ & $4.0 \pm 1.0$ & 0.2 & 0.3 \\
\hline
\end{tabular}

Table 2. Qualities valued in coaching

\begin{tabular}{|c|c|c|c|c|c|}
\hline & All & IEC & EC & & \\
\hline Variable & $\begin{array}{l}\text { Mean } \\
\pm \text { SD }\end{array}$ & $\begin{array}{l}\text { Mean } \\
\pm \text { SD }\end{array}$ & $\begin{array}{l}\text { Mean } \\
\pm \text { SD }\end{array}$ & $\begin{array}{l}\text { Effect } \\
\text { Size }\end{array}$ & $\begin{array}{c}\text { p- } \\
\text { value }\end{array}$ \\
\hline $\begin{array}{l}\text { Keeping up-to-date with the } \\
\text { latest developments in } \\
\text { coaching }\end{array}$ & $4.2 \pm 0.9$ & $4.1 \pm 1.0$ & $4.3 \pm 0.8$ & 0.2 & 0.1 \\
\hline $\begin{array}{l}\text { Improving my educational } \\
\text { qualifications }\end{array}$ & $4.2 \pm 0.9$ & $4.2 \pm 1.0$ & $4.3 \pm 0.9$ & 0.1 & 0.6 \\
\hline $\begin{array}{l}\text { Success of athletes under my } \\
\text { supervision }\end{array}$ & $4.2 \pm 0.8$ & $4.1 \pm 1.0$ & $4.3 \pm 0.9$ & 0.2 & 0.1 \\
\hline $\begin{array}{l}\text { Having a good rapport with } \\
\text { my athletes }\end{array}$ & $4.1 \pm 0.9$ & $4.0 \pm 1.0$ & $4.2 \pm 0.9$ & 0.2 & 0.1 \\
\hline $\begin{array}{l}\text { Having a good rapport with } \\
\text { support personnel (including } \\
\text { sport scientists) }\end{array}$ & $4.0 \pm 0.9$ & $3.9 \pm 0.9$ & $4.1 \pm 0.9$ & 0.2 & 0.1 \\
\hline $\begin{array}{l}\text { Using the latest methods/ } \\
\text { technology (where proven) }\end{array}$ & $4.0 \pm 1.0$ & $3.8 \pm 1.0$ & $4.1 \pm 0.9$ & 0.3 & $0.0^{*}$ \\
\hline $\begin{array}{l}\text { Many years of coaching } \\
\text { experience }\end{array}$ & $3.7 \pm 1.0$ & $3.6 \pm 0.9$ & $3.9 \pm 1.0$ & 0.3 & $0.0^{*}$ \\
\hline Being a former elite athlete & $3.6 \pm 1.1$ & $3.7 \pm 1.4$ & $3.5 \pm 1.2$ & 0.2 & 0.3 \\
\hline $\begin{array}{l}\text { Keeping up-to-date with the } \\
\text { latest developments in } \\
\text { coaching }\end{array}$ & $4.2 \pm 0.9$ & $4.1 \pm 1.0$ & $4.3 \pm 0.8$ & 0.2 & 0.1 \\
\hline $\begin{array}{l}\text { Improving my educational } \\
\text { qualifications }\end{array}$ & $4.2 \pm 0.9$ & $4.2 \pm 1.0$ & $4.3 \pm 0.9$ & 0.1 & 0.6 \\
\hline
\end{tabular}

\section{Research instrument}

A questionnaire adapted from Williams ${ }^{[8]}$ was used to gather information about coaches' perceptions of their sports science and research needs. Some of the items were modified to ensure suitability and applicability to the South African context. The questionnaire consisted of the following four areas: preference for research needs, qualities valued in coaching, practical application of sports science, and coach education and knowledge. All items were scored on a five-point Likert scale ranging from 1 (strongly disagree) to 5 (strongly agree). In order to determine the reliability of the questionnaire, the Cronbach alpha was computed which yielded a coefficient of 0.90 .

\section{Data collection procedure}

Prior to data collection, this study received clearance from the Ethics Committee of the University of Johannesburg. Informed consent was sought from the participants after the purpose of the study and data collection procedures were clearly explained to them. The principal researcher and trained fieldworkers administered the questionnaires to the participants, who were guided to complete the instrument independently. It took not more than 10 minutes to complete the questionnaires.

\section{Statistical analysis}

Descriptive statistics methods such as, means and standard deviations, were used to analyse the data. The data collected were initially tested for normality of distribution before the actual analysis. The independent $t$-test was applied to examine significant differences between experienced and inexperienced coaches. Effect size (ES) values of $0.2,0.5$, and 0.8 represented small, medium, and large differences, respectively. ${ }^{[9]}$ The alpha level was set at 0.05 . Statistical analyses were performed using the Statistical Package for Social Sciences (SPSS Version 24).

\section{Results}

Table 1 shows the most preferred areas of research according to coaching experience. The most preferred areas of research reported by sports coaches were "Improving the technique/efficiency of athletes" $(4.3 \pm 0.8)$, "Reducing the incidence of injury/illness in athletes" (4.3 \pm 0.8$)$, "Helping athletes peak for competition" (4.3 \pm 0.9$)$, and "Mental preparation of athletes" (4.3 \pm 1.0$)$. Statistically significant differences between the mean values of experienced and inexperienced coaches on the items "Reducing the incidence of injury/illness in athletes" $(t[188]=-1.970, \mathrm{p}$ $=0.0, \mathrm{ES}=0.3)$ and "Mental preparation of athletes" $(t$ $[188]=-2.058, \mathrm{p}=0.0, \mathrm{ES}=0.3$ ) were found .

The qualities most valued by sports coaches were as follows: "Keeping up-to-date with the latest developments in coaching" (4.2 \pm 0.9$)$, "Improving my educational qualifications" (4.2 \pm 0.9$)$, "Success of athletes under my supervision" $(4.2 \pm 0.8)$ and "Having a good

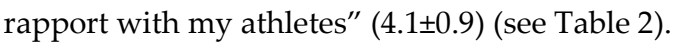

There were significant differences in the mean scores for inexperienced and experienced coaches on the following items: "Using the latest methods/technology" $(t[190]=-2.317, \mathrm{p}=0.0$, $\mathrm{ES}=0.3)$ and "Many years of coaching experience " $(t[189]=-$ $2.368, \mathrm{p}=0.0, \mathrm{ES}=0.3$ ). Table 3 shows the practical application 
Table 3. Practical application of sports science research

\begin{tabular}{|c|c|c|c|c|c|}
\hline & All & IEC & EC & & \\
\hline Variable & $\begin{array}{l}\text { Mean } \\
\pm \text { SD }\end{array}$ & $\begin{array}{l}\text { Mean } \\
\pm \text { SD }\end{array}$ & $\begin{array}{l}\text { Mean } \\
\pm \text { SD }\end{array}$ & $\begin{array}{l}\text { Effect } \\
\text { Size }\end{array}$ & $\begin{array}{c}\mathrm{p}- \\
\text { value }\end{array}$ \\
\hline $\begin{array}{l}\text { Technical aspects of coaching } \\
\text { need to be based on sports } \\
\text { science/sports medicine } \\
\text { research }\end{array}$ & $3.7 \pm 0.9$ & $3.7 \pm 0.9$ & $3.8 \pm 0.8$ & 0.1 & 0.1 \\
\hline $\begin{array}{l}\text { I need more research that is } \\
\text { based in 'natural' settings }\end{array}$ & $3.7 \pm 0.9$ & $3.6 \pm 0.9$ & $3.9 \pm 1.9$ & 0.2 & $0.0^{*}$ \\
\hline $\begin{array}{l}\text { Sports science/sports medicine } \\
\text { research influences what I do } \\
\text { with the athletes }\end{array}$ & $3.7 \pm 1.0$ & $3.5 \pm 0.9$ & $3.8 \pm 1.0$ & 0.3 & $0.0^{*}$ \\
\hline $\begin{array}{l}\text { Performance-based research is } \\
\text { only of value to me if my } \\
\text { athletes participated in the } \\
\text { study }\end{array}$ & $3.4 \pm 1.1$ & $3.4 \pm 1.1$ & $3.4 \pm 1.1$ & 0.0 & 0.9 \\
\hline $\begin{array}{l}\text { Sports science researchers do } \\
\text { not need to have coaching } \\
\text { experience }\end{array}$ & $3.0 \pm 1.3$ & $2.9 \pm 1.3$ & $3.1 \pm 1.3$ & 0.2 & 0.3 \\
\hline
\end{tabular}

Table 4. Coach education and sports science knowledge

\begin{tabular}{lcccccc}
\hline \multicolumn{1}{c}{ Variable } & All & IEC & EC & & \\
\cline { 2 - 4 } & $\begin{array}{c}\text { Mean } \\
\pm \text { SD }\end{array}$ & $\begin{array}{c}\text { Mean } \\
\pm \text { SD }\end{array}$ & $\begin{array}{c}\text { Mean } \\
\pm \text { SD }\end{array}$ & $\begin{array}{c}\text { Effect } \\
\text { Size }\end{array}$ & $\begin{array}{c}\text { p- } \\
\text { value }\end{array}$ \\
\hline $\begin{array}{l}\text { There is a need/role for sports } \\
\text { science researchers to translate }\end{array}$ & $3.9 \pm 1.0$ & $3.9 \pm 1.0$ & $4.0 \pm 1.1$ & 0.1 & 0.2 \\
$\begin{array}{l}\text { scientific literature into easily } \\
\text { understandable language }\end{array}$ & & & & & \\
$\begin{array}{l}\text { Sports science knowledge is } \\
\text { important for me to be a good } \\
\text { coach }\end{array}$ & $3.9 \pm 1.0$ & $3.9 \pm 1.0$ & $3.9 \pm 1.0$ & 0.0 & 0.9 \\
$\begin{array}{l}\text { I should have enough } \\
\text { scientific knowledge to be able } \\
\text { to read sports science journals }\end{array}$ & $3.7 \pm 1.0$ & $3.7 \pm 0.9$ & $3.7 \pm 1.1$ & 0.0 & 0.12 \\
$\begin{array}{l}\text { Sports science research takes } \\
\text { too long to answer coaching } \\
\text { questions }\end{array}$ & $3.3 \pm 1.0$ & $3.3 \pm 0.9$ & $3.3 \pm 1.1$ & 0.0 & 0.6 \\
* Significant at $p<0.05$. IEC, inexperienced coaches; EC, experienced coaches & & & \\
\hline
\end{tabular}

of sports science research according to coaching experience. Sports coaches rated the following as the most important items: "Technical aspects of coaching need to be based on sports science/sports medicine research" (3.7 \pm 0.9$)$, "I need more research that is based in 'natural' settings" $(3.7 \pm 0.9)$ and "Sports science/sports medicine research influences what I do with the athletes" (3.7 \pm 1.0$)$.

Significant differences were found in the following variables: "I need more research that is based in 'natural' settings" $(t[190]=-2.151, \mathrm{p}=0.0, \mathrm{ES}=0.2)$ and "Sports science/sports medicine research influences what I do with the athletes $(t[190]=-1.961, \mathrm{p}=0.0 . \mathrm{ES}=0.3)$.

Table 4 summarises results for coach education and sports science knowledge according to coaching experience. Sports coaches indicated that "There is a need/role for sports science researchers to translate scientific literature into easily understandable language" (3.9 \pm 1.0$)$ and "Sports science knowledge is important for me to be a good coach" $(3.9 \pm 1.0)$.

\section{Discussion}

This study found that improving the technique/efficiency of athletes was identified as the most important area of interest by sports coaches. This finding is congruent with that of previous studies which perceived biomechanics as the scientific domain of most benefit to coaches. ${ }^{[8,10]}$ Reducing the incidence of injury/illness in athletes and helping them peak for competition were the other imperative factors identified as beneficial to coaches. The literature indicates that peaking for competition entails the physiological manipulation of training intensity and volume based on the principle of periodisation. ${ }^{[8]}$ Therefore, it could be deduced that with an improvement in technical skills, a discipline addressed in biomechanics and physiology, is related to reducing the incidence of injury. ${ }^{[8]}$ The reason why sports coaches stressed the priority of reducing the frequency of injury/illness among athletes could be that the majority of them were involved in contact sports (e.g. rugby, soccer, etc.) which have a higher occurrence of injuries.

The preference for physiology-based research may be twofold: firstly, the fundamental requirements of most sports is for athletes to develop appropriate aerobic and anaerobic fitness, and secondly, researchers work more in the area of physiology than in other areas, such as sports medicine and sports physiotherapy. ${ }^{[5]}$ Another important area of benefit which emerged from this study relates to the mental preparation of athletes. Previous research [7] reported that sports coaches had limited knowledge of mental preparation for athletes despite it being very necessary. Nevertheless, in line with the assertion of William and Kendall [5], there are few sports psychologists working with highperformance athletes in South Africa, and they focus mainly on servicing the athletes rather than on conducting research based in the natural setting.

Sports coaches indicated that keeping up to date with the latest developments and research in coaching was very important, which complemented the findings in the literature ${ }^{[4]}$ Coaches who keep up to date with the latest developments in their particular sports may be more receptive to trying new ideas through research which would in turn assist in maximising their athletes' performance. ${ }^{[8,11]}$ Sports coaches also indicated the importance of improving their educational qualifications as part of their continuous professional development. Those who did not play at the professional level are denied opportunities to work at a high-performance level in South Africa. ${ }^{[12]}$

The success of athletes under a coach's supervision was also regarded as the most important aspect in coaching, especially in South Africa. The high emphasis placed on "Having a good rapport with my athletes" acknowledges the importance of having good professional relationships between coaches and athletes, as well as a valuing of interpersonal skill above the need for scientific knowledge. ${ }^{[6]}$ In contrast to previous research that found that many years of coaching experience was an important quality valued in coaching, ${ }^{[9]}$ the present study 
found that coaching experience was the least important of the qualities reported by sports coaches. The fact that South African coaches are not hired and promoted based on their many years of coaching but on their qualifications probably explains this finding.

Sports coaches agreed that the technical aspects of coaching need to be based on sports science/sports medicine research. This finding demonstrates that there appears to be a huge gap between what researchers are doing and the knowledge that coaches need. This statement is supported by Reade et al. [7] who reported that there are gaps between the focus of sports science research and coaches' expectations. This finding has implications for policymakers and sports researchers to reinforce existing consultative discussion to determine the needed research focus. ${ }^{[9]}$ Therefore, this study demonstrates that sports scientists and coaches should work together to integrate research into practice to address coaching problems. A sports science researcher should be guided by the philosophy in which useful findings are provided that could enhance the development of athletes and coaches, as development is synonymous with a successfully integrated research-practice model. [13]

Coaches further indicated that there is a need for sports scientists to translate scientific journals into easily understandable language, a finding that supports previous literature. ${ }^{[5,8]}$ Admittedly, most coaches are unfamiliar with research methodology, statistics, jargon, concepts and terminologies often used by sports scientists, and they lack the basic background knowledge of sports science and/or necessary educational background to interpret research findings and apply the latest information to coaching practice. If the results of sports science research are not presented in understandable ways, they cannot be properly applied to address practical issues in sports coaching. There is a need for the better translation and dissemination of sports science information so that it is easily understood by coaches. This could be achieved through organising workshops, seminars, and short learning courses targeted at sports scientists and coaches. ${ }^{[14,15]}$

The coaches further reported that sports science knowledge is important for them to be good coaches and that they should have sufficient scientific background to be able to read sports science journals. In addition, the coaches agreed that it takes too long for sports science research to answer issues related to the practical aspects of coaching. This could be attributed to the fact that sports science investigations generally require long-term data collection. ${ }^{[4]}$ Bishop et al. ${ }^{[2]}$ contend that it does not matter how long sports scientists take to collect data, the most important thing is that they should put into practice the information obtained from the research process to improve the performance and/or training of an athlete.

\section{Conclusion}

Based on the outcome of this study, the coaches indicated a dire need for research in the following areas: improving the technique/efficiency of athletes, reducing the incidence of injury/illness in athletes, helping athletes peak for competition, and the mental preparation of athletes.
Furthermore, coaches reported that sports scientists should present scientific articles in language which is user-friendly. Thus, it is imperative to organise sports science workshops and seminars regularly for coaches to keep them abreast with the latest trends and developments in coaching.

\section{References}

1. Bishop D. An applied research model for the sport sciences. Sports Med 2008; 38(3): 253-263. [doi:10.2165/00007256200838030-00005]

2. Bishop D, Burnett A, Farrow D, et al. Sports-science roundtable: does sports-science research influence practice. Int J Sports Physiol Perform 2006; 1(2): 161-168. [doi:10.1123/ijspp.1.2.161]

3. Amusa LO, Toriola AL. Challenges for African sports scientists: Bridging the gap between theory and practice. Afri J Phys Health Educ Recreat Dance 2004; 10(1): 1-19.

4. Haff GG. Sport science. Strength Cond J 2010; 32(2): 33-45. [doi: 10.1519/ssc.0b013e3181d59c74]

5. Williams SJ, Kendall L. Perceptions of elite coaches and sports scientists of the research needs for elite coaching practice. J Sports Sci 2007; 25(14): 1577-1586. [doi10.1080/02640410701245550]

6. Reade I, Rodgers W, Hall N. Knowledge transfer: How do high performance coaches access the knowledge of sport scientists? Int J Sports Sci Coach 2008; 3(3): 319-334. [doi:10.1260/174795408786238470]

7. Kilic K, Ince ML. Use of sports science knowledge by Turkish coaches. Int J Exerc Sci 2015; 8(1): 21-37.

8. Williams SJ. A case study of the relationship between sports science research practice and elite coaches perceived needs. Unpublished doctoral thesis. University of Canberra, 2005. http://www.canberra.edu.au/researchrepository/items/0de68d3b -025b-da67-44dc-f4551a12f504/1/

9. Cohen J. Statistical power analysis for the behavioral sciences $\left(2^{\text {nd }}\right.$ ed.). Hillsdale, NJ: Lawrence Erlbaum, 1988:20-26.

10. Mooney R, Corley G, Godfrey A, et al. Analysis of swimming performance: perceptions and practices of US-based swimming coaches. J Sports Sci 2016; 34(11): 997-1005. [doi:10.1080/02640414.2015.1085074]

11. Williams J. What are the research needs of elite coaches? Australian Sports Commission 2006; 29(2). https://ausport.gov.au (accessed 16 June 2017).

12. Kubayi NA, Coopoo Y, Morris-Eyton HF. Job-related barriers encountered by football coaches in Gauteng Province of South Africa: management and governance - sport management and governance. Afri J Phys Health Educ Recreat Dance 2015; November (Suppl. 1): 160-166.

13. Jones B, Till K, Emmonds S, et al. Accessing off-field brains in sport; an applied research model to develop practice. Br J Sports Med 2016; pii: bjsports-2016-097082. [doi:10.1136/bjsports-2016097082]

14. Hendricks S, Sarembock M, Jones B, et al. The tackle in South African youth rugby union-Gap between coaches' knowledge and training behaviour. Int J Sports Sci Coach 2017; 12(6): 708 715. [doi:10.1177/1747954117738880]

15. Hendricks S, Sarembock M. Attitudes and behaviours of top-level junior rugby union coaches towards the coaching of proper contact technique in the tackle-a pilot study. S Afr J Sports Med 2013; 25(1): 8-11. [doi:10.7196/SAJSM.459] 